\title{
Developmental Differences of Cystic Fibrosis Transmembrane Conductance Regulator Functional Expression in Isolated Rat Fetal Distal Airway Epithelial Cells
}

\author{
R. JOHN MACLEOD, J. R. HAMILTON, H. KOPELMAN, AND NEIL B. SWEEZEY \\ McGill University-Montreal Children's Hospital Research Institute, Department of Paediatrics, McGill \\ University, Montreal, Quebec, Canada
}

\begin{abstract}
Fluid secretion from the pulmonary epithelium may play a significant role in determining intrauterine lung development. We used suspensions of distal pulmonary epithelial cells isolated from rat fetuses to assess a shift in secretory mechanisms occurring in the lung of this species during late gestation. The impact of cAMP on distal airway epithelial cells isolated from d 18 to $\mathrm{d} 21$ rat fetuses was evaluated with measurements of cell volume and ${ }^{36} \mathrm{Cl}$ efflux rates. At d 18, 8-Br-cAMP stimulated a volume reduction measured by electronic cell sizing that was prevented by the $\mathrm{Cl}^{-}$channel blocker anthracene-9carboxylate (A-9C) and reflected in an increased rate of A$9 \mathrm{C}$ sensitive ${ }^{36} \mathrm{Cl}$ efflux. Because the cystic fibrosis transmembrane conductance regulator (CFTR) is thought to be a cAMP-regulated $\mathrm{Cl}^{-}$channel, we measured the effect of prior cell incubation with oligodeoxynucleotides antisense to the transcription site of the human CFTR gene on these events. We found that in antisense oligomer-treated cells, but not in sense oligomer-treated controls, volume and ${ }^{36} \mathrm{Cl}$ efflux responses to 8-Br-cAMP were prevented in d 18 cells. In d 21 cells, 8-Br-cAMP did not stimulate volume reduction but the calcium ionophore $\mathbf{A 2 3 1 8 7}$ did elicit cell volume reduction in cells suspended in an isotonic $\mathrm{Ca}^{2+}$. containing medium that was prevented by A-9C. This response to the ionophore was not found in the $d 18$ cells, and incubation with the antisense CFTR oligomer had no effect on the ionophore-induced responses in $d 21$ cells. Our results suggest that CFTR mediates cAMP-stimulated $\mathrm{Cl}^{-}$conductance in d 18 rat fetal distal pulmonary epithelial cells. Furthermore, during fetal growth between $\mathrm{d} 18$ and 21 there is a reciprocal pattern whereby $\mathrm{Ca}^{2+}$-activated $\mathrm{Cl}^{-}$ conductance appears whereas CFTR disappears in the distal pulmonary epithelium. (Pediatr Res 35: 45-49, 1994)
\end{abstract}

\section{Abbreviations}

CFTR, cystic fibrosis transmembrane conductance regulator

oligodNT, oligodeoxynucleotide

MEM, minimal essential medium

HEPES, $\quad N$-2-hydroxyethylpiperazine- $N^{\prime}$-2-ethanesulfonic acid

Received February 8, 1993; accepted August 18, 1993.

Correspondence: R. John MacLeod, McGill University-Montreal Children's Hospital Research Institute, Department of Paediatrics, 2300 Tupper Street, Montreal, Quebec, H3H IP3 Canada.

Supported by grants from the Medical Research Council of Canada (J.R.H.), the Canadian Cystic Fibrosis Foundation (H.K.), and the Quebec Lung Association (N.B.S.). H. Kopelman is a recipient of a Canadian Cystic Fibrosis Foundation Scholar Award.
RPMI, Roswell Park Memorial Institute
A-9C, anthracene-9-carboxylate
24-mer, 24 base-pair oligodeoxynucleotide

Fluid secretion by the fetal lung is essential for lung morphogenesis $(1,2)$ but the contribution of developing distal pulmonary epithelium to this fluid secretion is not known (3). Fetal rat lungs at d 18 gestational age are in the pseudoglandular stage of development whereas 19 and $21 \mathrm{~d}$ gestational age represent the transition between canalicular and saccular stages of lung development (4). If fluid secretion in developing rat distal pulmonary epithelium is similar to models proposed for other epithelia (58 ), it can be assumed to be associated with a $\mathrm{Cl}^{-}$conductance activated by cAMP $(3,9)$. CFTR, a cAMP-regulated $\mathrm{Cl}^{-}$channel (10), has been demonstrated in second trimester human fetal lung (9). These findings suggest that CFTR plays a role in mediating cAMP-stimulated $\mathrm{Cl}^{-}$efflux from secretory distal pulmonary epithelium before it differentiates to a net $\mathrm{Na}^{+}$-absorbing epithelium before birth (4).

In a different model of a secretory epithelium, the measurement of rapid alterations in isotonic cell volume $(11,12)$, reduced cell ${ }^{36} \mathrm{Cl}$ content (13), together with the activation of $\mathrm{K}^{+}$channels (14) and $\mathrm{Cl}^{-}$currents (15) have been used to evaluate secretory responses to cholinergic stimulation. Accordingly, we determined the isotonic volume changes stimulated by cAMP in primary cultures of rat distal airway epithelial cells isolated at gestational ages (d 18-21) which is the developmental period when the transition of net ion secretion to net ion absorption occurs (4). We used volume reduction and $\mathrm{Cl}^{-}$channel blocker-sensitive ${ }^{36} \mathrm{Cl}$ efflux stimulated by cAMP as an assay of the functional expression of cAMP-stimulated $\mathrm{Cl}^{-}$conductance. We proposed that if CFTR did mediate cAMP-dependent $\mathrm{Cl}^{-}$secretion, then treatment of the secretory cells (gestational age $d$ 18) with oligodNT antisense to the CFTR gene transcript would prevent cAMP-stimulated ${ }^{36} \mathrm{Cl}$ efflux and isotonic volume reduction. Our results provide new insight into the regulation of $\mathrm{Cl}^{-}$conductance in developing rat distal pulmonary epithelium.

\section{MATERIALS AND METHODS}

Isolation of fetal alveolar epithelial cells. Fetal rat distal airway epithelial cells were prepared in monolayer culture on plastic using the method of Post(16). Cells were grown to confluence in MEM with $10 \%$ FCS ( $24 \mathrm{~h})$, and then assessed by light microscopy after incubation for a further $48 \mathrm{~h}$ in serum-free medium at confluence. Consistent with previous reports $(17,18,19)$ these 
fetal distal airway epithelial cells were homogeneous in their staining of intermediate filaments, and viable ( $>95 \%$ extruded trypan blue). The d 18 fetal distal airway epithelial cells showed no tannic acid staining of lamellar bodies, whereas $d 21$ epithelial cells showed abdundant tannic acid staining of lamellar bodies. These cells retained differentiated function throughout the periods of testing used in the present study. Cells were detached from flasks by 10 min trypsinization $\left(0.0625 \%\right.$ in MEM) at $20^{\circ}$ C, rinsed twice with $\mathrm{MEM} / 10 \%$ FCS, filtered through a Nitex $(100 \mu \mathrm{m}$ pore size) filter, and then suspended in HEPES buffered RPMI 1640 medium, pH 7.3, for cell volume measurements. Trypsinization had no effect on the cAMP- or calcium ionophore-stimulated volume changes of the distal airway epithelial cells.

Antisense oligodNT. A 24-mer complementary (antisense) and homologous (sense) to the human CFTR transcript were synthesized on a Pharmacia Gene Assembler/Synthesizer, cleaved and purified using Sephadex G-50 (Nick column, Pharmacia, Piscataway, NJ) according to the manufacturer's protocol. Both oligodNT code for bases 14 to 37 from the transcription initiation site as originally reported (20). Fetal alveolar cells at confluence were rinsed with PBS, then placed in serum-free MEM. Either the antisense oligodNT (5'-TTTCTCTGACCTGCTGTGATGTCA-3') or the sense oligodNT ( $5^{\prime}$-TGACATCACAGCAGGTCAGAGAAA-3') was added at $1.5 \mu \mathrm{M}$ (final concentration) and incubated with the cells for $24 \mathrm{~h}$. Fetal distal airway epithelial cells were then detached, as described above, for cell volume or ${ }^{36} \mathrm{Cl}$ efflux experiments. Screening of the antisense oligodNT for homology with other genes was performed using PC/Gene (IntelliGenetics, Inc., Mountain View, CA).

Cell volume determination. Cell volume was measured using a Coulter Counter (model $\mathrm{Zm}$ ) with an attached Channelyzer (C-256), as previously described $(21,22)$. Relative cell volume was determined as the ratio of cell volume under study conditions to the volume under basal conditions in the isotonic medium immediately before challenge. Cell volume measurements were made using 30000 cells $/ \mathrm{mL}$ in a medium which contained (in $\mathrm{mM}$ ): $140 \mathrm{NaCl}, 3 \mathrm{KCl}, 1 \mathrm{CaCl}_{2}, 1 \mathrm{MgCl}_{2}, 10 \mathrm{D}$-glucose, and 10 HEPES (pH 7.3, 295 mosmol/kg). 8-Br-cAMP (0.5 mM, final) or calcium ionophore, A23187 (3 $\mu \mathrm{M}$, final) was added directly to the cells. The solvent vehicle $(0.1 \% \mathrm{DMSO})$ for the ionophore had no effect on the isotonic volume of cells.

${ }^{36} \mathrm{Cl}$ efflux. Fetal distal airway epithelial cells $\left(1 \times 10^{6}\right.$ cells $/$ $\mathrm{mL})$ were loaded with ${ }^{36} \mathrm{Cl}(8 \mu \mathrm{Ci} / \mathrm{mL})$ in $\mathrm{HCO}_{3}$-free $\mathrm{RPMI}$ medium for $40 \mathrm{~min}$, then diluted 5 -fold with ${ }^{36} \mathrm{Cl}$-free medium, centrifuged and resuspended in isotonic HEPES-buffered $\mathrm{Na}^{+}$ medium, pH 7.3 at $5 \times 10^{6}$ cells $/ \mathrm{mL}$. 8 -Br-cAMP $(0.5 \mathrm{mM})$ was added to the suspension, and after $2 \mathrm{~min}, 500 \mu \mathrm{L}$ of cell suspension were removed and added to an equal volume of ice-cold isotonic $\mathrm{Na}^{+}$gluconate medium (with gluconate isotonically replacing all $\left.\mathrm{Cl}^{-}\right)$which served as a "stop" solution $(23,24)$. For inhibitor experiments, A-9C $(300 \mu \mathrm{M})$ was added to a fraction of cells after resuspension. After dilution in stop solution, an aliquot of this mixture was layered over $100 \mu \mathrm{L}$ of a $3: 2(\mathrm{vol} /$ vol) di-n-butylphthalate/di-n-nonylphthalate oil preparation and centrifuged at $1300 \times g$ for $20 \mathrm{~s}$ in a microfuge. We then aspirated the supernatant and oil, solubilized the cell pellet with $1 \%$ SDS and measured the isotope remaining in the cells with liquid scintillation counting. Sampling was done in duplicate. Results are expressed as fraction of ${ }^{36} \mathrm{Cl}$ lost compared with cells diluted isotonically.

Reagents. A-9C was from Aldrich Chemical (Milwaukee, WI), RPMI 1640 medium from Gibco/BBL (Burlington, Ontario), and dinonylpthalate from Pfaltz and Baur (Waterbury, CT). $\mathrm{Na}^{36} \mathrm{Cl}$ was from ICN (Montreal, Quebec).

Statistics. Data are reported as means of six to seven experiments performed in duplicate for the volume determinations, and five experiments for the ${ }^{36} \mathrm{Cl}$ efflux measurements. Differ- ences in means were determined using $t$ test, or analysis of variance, as appropriate.

\section{RESULTS}

The effect of 8-Br-cAMP on the volume of $\mathrm{d} 8$ fetal distal epithelial cells suspended in an isotonic medium is illustrated in Figure 1. Within $30 \mathrm{~s}$ of the addition of 8 -Br-cAMP $(0.5 \mathrm{mM})$ relative cell volume became less than that of controls $(0.96 \pm$ $0.01 ; p<0.001 ;$ Fig. $1 A$ ). This volume reduction progressed over the course of the experiment, when the relative volume remained less than that of untreated controls $(0.85 \pm 0.01$ versus $0.94 \pm$ $0.01 ; p<0.001$ ). Untreated control cells shrank $\simeq 6 \%$ over the study period. A-9C, an established $\mathrm{Cl}^{-}$channel blocker in tracheal and intestinal epithelia (22-25) prevented the cAMP-stimulated volume reduction (Fig. $1 B$ ). The final relative cell volume in A-9C $(300 \mu \mathrm{M})$ with 8-Br-cAMP was greater than for cells exposed only to 8 -Br-cAMP $(0.94 \pm 0.01$ versus $0.85 \pm 0.01 ; p$ $<0.001)$. $\mathrm{A} \mathrm{K}^{+}$channel blocker, $\mathrm{Ba}^{2+}(5 \mathrm{mM})$ also prevented 8 Br-cAMP-stimulated volume reduction; the final relative cell volume in $\mathrm{Ba}^{2+}$ with $8-\mathrm{Br}$-cAMP was greater than with $8-\mathrm{Br}$ cAMP alone $(0.94 \pm 0.01$ versus $0.85 \pm 0.01 ; p<0.001)$. These results suggested that the volume reduction caused by cAMP in the $\mathrm{d} 18$ fetal distal airway epithelial cells was due to the activation of $\mathrm{K}^{+}$and $\mathrm{Cl}^{-}$channels and that the subsequent salt loss, together with osmotically obliged water, resulted in a volume reduction.

We determined whether cAMP directly activated $\mathrm{Cl}^{-}$conductance in the $\mathrm{d} 18 \mathrm{fetal}$ distal airway cells by measuring the rate of ${ }^{36} \mathrm{Cl}$ efflux from these cells challenged with $8-\mathrm{Br}$-cAMP under isotonic conditions (Fig. $2 A$ ). As predicted from the volume experiments, 8-Br-cAMP substantially increased the rate of ${ }^{36} \mathrm{Cl}$ efflux in comparison with controls (fraction ${ }^{36} \mathrm{Cl}$ lost $/ 2 \mathrm{~min}$, $0.33 \pm 0.03$ versus $0.09 \pm 0.01 ; p<0.001)$. A-9C inhibited the 8-Br-cAMP increased rate of efflux $(0.12 \pm 0.01 ; p<0.001)$. Clearly, the 8-Br-cAMP-stimulated volume reduction was associated with an increase in the rate of $\mathrm{A}-9 \mathrm{C}$ sensitive ${ }^{36} \mathrm{Cl}$ efflux.

Because treatment with oligodNT antisense to the CFTR gene transcript is known to inhibit $\mathrm{Cl}^{-}$transport in sweat gland epithelium (26), we incubated d 18 fetal alveolar cells with oligodNT antisense to the transcriptional site of human CFTR $(1.5 \mu \mathrm{M}, 24 \mathrm{~h})$ and compared their volume response to $8-\mathrm{Br}$ cAMP with cells comparably treated with the sense oligodNT (Fig. 2B). Volume reduction caused by 8 -Br-cAMP was prevented in $d 18$ cells treated with antisense CFTR oligodNT but not in 18 cells treated with sense CFTR oligodNT (final relative volume, sense $0.88 \pm 0.01$ versus antisense $0.93 \pm 0.01 ; p<$ 0.001 ). There was no difference in the rate of ${ }^{36} \mathrm{Cl}$ efflux from $\mathrm{d}$ 18 cells treated with sense CFTR oligodNT compared with

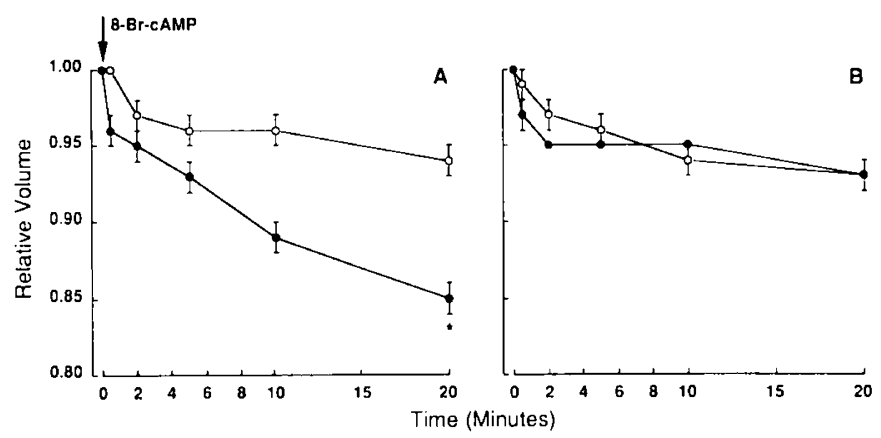

Fig. 1. Effect of 8-Br-cAMP and channel blockers on isotonic d 18 fetal alveolar epithelial cell volume. $A, \mathrm{O}$, isotonic, no additions; $\bullet, 8$ $\mathrm{Br}$-cAMP $(0.5 \mathrm{mM}) ;{ }^{*} p<0.001$ compared with isotonic. $B, \mathrm{O}, \mathrm{Ba}^{2+}(5$ $\mathrm{mM}), 8$-Br-cAMP;, $\mathrm{A}-9 \mathrm{C}(300 \mu \mathrm{M})$. Volumes were measured electronically and are expressed relative to isotonic control. Mean $\pm S E$ of seven experiments are reported. 

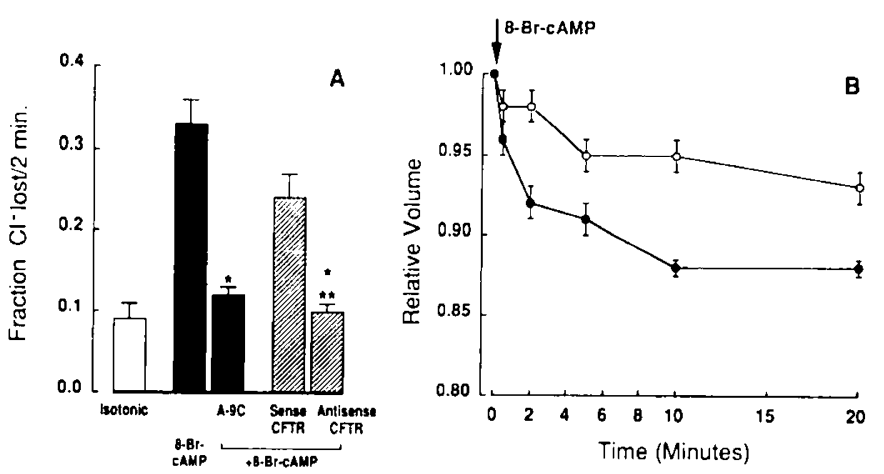

Fig. 2. Effect of antisense oligodNT to the CFTR on 8-Br-cAMPstimulated ${ }^{36} \mathrm{Cl}$ efflux and isotonic cell volume from $\mathrm{d} 18$ fetal alveolar epithelial celis. $A$, Rate of ${ }^{36} \mathrm{Cl}$ efflux from cells after 8-Br-cAMP addition, in the presence of $\mathrm{A}-9 \mathrm{C}(300 \mu \mathrm{M})$ or after incubation for $24 \mathrm{~h}$ with sense or antisense CFTR oligodNT. ${ }^{*} p<0.001$ vs CAMP; ${ }^{* *} p<0.01$ vs sense oligomer. Mean $\pm \mathrm{SE}$ of the fractional loss of ${ }^{36} \mathrm{Cl}$ of five experiments are reported. $B$, Volume response of $\mathrm{d} 18$ fetal alveolar cells to $8-\mathrm{Br}$ cAMP after incubation with either 9 , sense CFTR oligomer $(1.5 \mu \mathrm{M}, 24$ h) or $O$, antisense CFTR oligomer $(1.5 \mu \mathrm{M}, 24 \mathrm{~h})$. Volume measured electronically, expressed relative to isotonic control. Mean $\pm \mathrm{SE}$ of seven experiments reported.

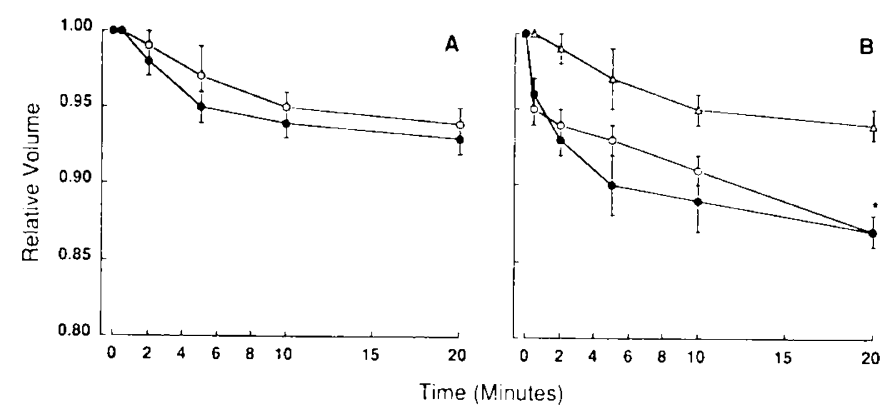

Fig. 3. Effect of 8-Br-cAMP or calcium ionophore A23187 on d 21 fetal alveolar epithelial cell volume. $A, \mathrm{O}$, isotonic, no additions; 9,8 $\mathrm{Br}$-cAMP $(0.5 \mathrm{mM}) . B, \Delta$, isotonic, $0.01 \%$ DMSO; $\mathrm{O}$, A23187 $(3 \mu \mathrm{M})$ in medium with $\left[\mathrm{Ca}^{2+}\right]=1 \mathrm{mM} ; \bullet$, cells incubated $24 \mathrm{~h}$ with antisense oligomer of CFTR $(1.5 \mu \mathrm{M})$ and $\mathrm{A} 23187(3 \mu \mathrm{M}){ }^{*} p<0.001 v$ s isotonic. Volume measured electronically, expressed relative to isotonic control. Mean \pm SE of six experiments reported.

untreated cells (Fig. 2A). However d 18 cells treated with antisense CFTR oligodNT demonstrated no increase in the rate of ${ }^{36} \mathrm{Cl}$ efflux after 8 -Br-cAMP addition (fraction ${ }^{36} \mathrm{Cl}$ lost/2 min, $0.10 \pm 0.01 ; p<.01)$. These results suggest that CFTR mediates cAMP-stimulated $\mathrm{Cl}^{-}$efflux in $\mathrm{d} 18 \mathrm{fetal}$ distal airway epithelial cells.

The effect of 8-Br-cAMP and of the calcium ionophore, A23187, on the isotonic volume of d 21 fetal distal airway epithelial cells is illustrated in Figure 3. In contrast with the $d 18$ cells, 8-Br-cAMP did not cause volume reduction, whereas the calcium ionophore did. There was no difference in the volume of d 21 cells challenged with 8-Br-cAMP compared with cells untreated in isotonic medium (final relative volume, $0.93 \pm 0.01$ versus $0.94 \pm .01$; Fig. $3 A$ ). In $\mathrm{Ca}^{2+}(1 \mathrm{mM})$-containing medium, cells treated with $\mathrm{A} 23187(3 \mu \mathrm{M})$ lost volume (final relative volume, $0.87 \pm 0.01$ versus $0.94 \pm 0.01 ; p<0.001$ ) compared with untreated cells (Fig. $3 B$ ). A-9C prevented this volume reduction $(0.94 \pm 0.01$ versus $0.87 \pm 0.01 ; p<0.001)$, a result that was consistent with $\mathrm{Cl}^{-}$efflux occurring through a conductive pathway. In contrast, addition of the calcium ionophore to d 18 cells in $\mathrm{Ca}^{2+}(1 \mathrm{mM})$-containing medium had no effect on their volume (final relative volume, $0.94 \pm 0.01$ versus $0.94 \pm$ 0.01 ). The d 21 fetal distal airway epithelial cells treated $24 \mathrm{~h}$ with antisense CFTR oligodNT also manifested isotonic volume reduction when challenged with A23187 (Fig. 3B) consistent with the $\mathrm{Ca}^{2+}$-activated $\mathrm{Cl}^{-}$conductance being distinct from CFTR (27).

In 19 cells, the 8-Br-cAMP-stimulated volume reduction was reduced $\simeq 60 \%(p<0.02)$ in comparison with d 18 cells (Fig. 4$)$. The magnitude of the A23187-stimulated volume reduction at $d$ 19 was less $(p<0.02)$ than at $d 21$ but volume reduction in $d$ 20 cells was the same as in $d 21$ cells. These results suggest that as the fetal distal airway cells differentiate from a secretory to absorptive epithelium, the functional expression of CFTR is lost, whereas the $\mathrm{Ca}^{2+}$-activated $\mathrm{Cl}^{-}$conductance is acquired.

\section{DISCUSSION}

The cAMP-induced volume reduction in d 18 cells occurred as a result of the activation of both $\mathrm{K}^{+}$and $\mathrm{Cl}^{-}$conductances as it was prevented by a $\mathrm{K}^{+}$channel blocker, $\mathrm{Ba}^{2+}(22)$, or a $\mathrm{Cl}^{-}$ channel blocker, A-9C $(23,25)$. This volume reduction occurred in parallel with a substantial increase in ${ }^{36} \mathrm{Cl}$ efflux which was prevented by the $\mathrm{Cl}^{-}$channel blocker. Our data demonstrate that the $\mathrm{Cl}^{-}$secretory response of $\mathrm{d} 18$ fetal distal airway epithelial cells to 8-Br-cAMP occurs through a conductive pathway and that in these cells in suspension this $\mathrm{Cl}^{-}$(and $\mathrm{K}^{+}$) efflux results in a volume reduction. In contrast, comparably isolated epithelial cells at gestational age $\mathrm{d} 21$ manifested no volume response when challenged with cAMP.

After d 18 fetal distal airway epithelial cells were incubated with oligodNT antisense to the transcriptional initiation site of human CFTR, the 8-Br-cAMP-stimulated ${ }^{36} \mathrm{Cl}$ efflux rate was diminished, and volume reduction was prevented. Antisense oligodNT targeted to several genes have been shown to block translation and lead to an absence or decrease of the gene product $(28,29)$. Indeed, antisense oligodNT to CFTR have been demonstrated to inhibit $\mathrm{Cl}^{-}$conductance in human sweat duct cells (26) and a human pancreatic duct cell line (30). Our results demonstrating that treatment of $d 18$ cells with antisense CFTR oligodNT prevented cAMP-stimulated volume reduction and ${ }^{36} \mathrm{Cl}$ efflux whereas sense CFTR oligodNT did not, are consistent with the interpretation that CFTR mediates cAMP-stimulated $\mathrm{Cl}^{-}$efflux in these cells. It has been reported that $\mathrm{d} 18$ rat fetal distal airway epithelial cells can form cystic, alveolar-like structures with a fluid filled lumen; the size of these cysts is increased by cAMP addition suggesting that these cells produce fluid by a $\mathrm{Cl}^{-}$conductance regulated by cAMP (3). Our results using the same tissue, confirm and extend these findings by directly measuring cAMP-stimulated, A-9C-sensitive ${ }^{36} \mathrm{Cl}$ efflux which we found prevented by antisense oligodNT of CFTR. Therefore we

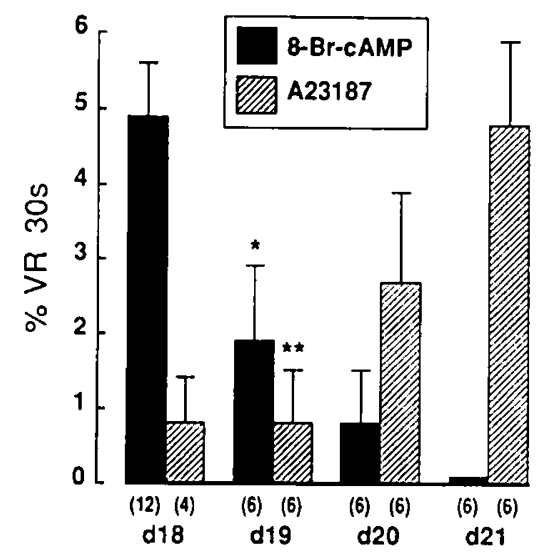

Fig. 4. Percent volume reduction (VR) at $30 \mathrm{~s}$ to either 8 -Br-cAMP or A23187 of fetal alveolar epithelial cells from d 18 to 21 of gestation. ${ }^{*} p<0.02$ vs d $18 ; * * p<0.02$ vs $\mathrm{d} 21$. Numbers in brackets are the number of experiments. Volume measured electronically, expressed relative to isotonic control. 
conclude that at $\mathrm{d} 18$ the fetal distal airway epithelial cells possess a cAMP-stimulated $\mathrm{Cl}^{-}$conductance that is mediated by CFTR.

Because the specificity of the antisense oligodNT technique has been questioned (31), we screened the 24-mer used in this study for homology with other genes and found 18 and 19 base pair (out of 24) homology with human immunoglobin $\mu$ and $\delta$ genes and human ryanodine receptor genes, respectively. Fifteen of a 19 nucleotide overlap were identical with human mRNA for type I $\beta$ cGMP-dependent protein kinase (EC 2.7.1.37). However, it is clear that for the antisense oligodNT technique to be specific, different antisense sequences of the target gene must give the same phenotype and control sequences must not (31). In a separate study using the identical 24-mer used in this study, we reported that oligodNT antisense to a different region of the CFTR gene transcript (bases 133-153 from the transcription initiation site) were also found to abolish the volume reduction of PANC-1 cells stimulated by cAMP but not the volume response to calcium ionophore A23187 (30) consistent with this 24-mer being specific for CFTR. Therefore, our antisense oligodNT results strongly suggest that CFTR mediates the cAMPstimulated $\mathrm{Cl}^{-}$conductance in the $\mathrm{d} 18$ fetal distal airway epithelial cells.

The $\mathrm{d} 21$ fetal distal airway epithelial cells shrank in response to calcium ionophore in $\mathrm{Ca}^{2+}$-containing medium. This volume reduction also was prevented by the $\mathrm{Cl}^{-}$channel blocker $\mathrm{A}-9 \mathrm{C}$, consistent with the presence in these cells of a Ca${ }^{2+}$-activated $\mathrm{Cl}^{-}$ conductive pathway. Comparable volume reduction stimulated by calcium ionophore has been reported in a human pancreatic duct cell line (30). Patch-clamping analysis of tracheal epithelium has demonstrated that the $\mathrm{Ca}^{2+}$-activated $\mathrm{Cl}^{-}$conductance is distinct from CFTR in that tissue (27). Our results showing that treatment with antisense oligodNT of CFTR had no impact on calcium ionophore's induced volume reduction in d 21 cells suggests that a similar situation exists in the distal lung. Volume reduction activated by $\mathrm{Ca}^{2+}$ ionophore was not detectable at $\mathrm{d}$ 18 and 19 , but could be observed in cells at $d 20$ and 21 suggesting that the $\mathrm{Ca}^{2+}$-activated $\mathrm{Cl}^{-}$conductance is developmentally expressed as these epithelial cells differentiate from a net secretory to absorptive phenotype (4). In rabbit fetal lung at gestational age $\mathrm{d} 22$ (pseudoglandular) CFTR was localized to the membrane regions of tubular epithelial cells but at d 29 (terminal sac) was concentrated in the apical region of bronchiolar epithelial cells and absent from alveoli (32). These results are consistent with our findings in rat fetal lung.

Our results demonstrating the progressive decline of the cAMP-stimulated volume reduction of cells isolated at gestational ages after $\mathrm{d} 18$ also suggest that the functional expression of CFTR is developmentally regulated, but in a manner which is reciprocal to that of the $\mathrm{Ca}^{2+}$-activated $\mathrm{Cl}^{-}$conductance. The roles of CFTR and cAMP-mediated fluid secretion in fetal lung fluid secretion and lung development in vivo are unknown. CFTR mRNA has been detected at low levels in both surface epithelium and the underlying lamina propria of the bronchi and bronchioles of adult rat lung (33) whereas other studies have described anatomically normal lungs in newborn and older human infants with cystic fibrosis $(34,35)$. These findings suggest that the cAMP-stimulated $\mathrm{Cl}^{-}$efflux mediated by CFTR does not play a significant role in the regulation of lung fluid in the fetus, as alteration of its function in cystic fibrosis has no impact on lung development (9). Because our results show an inverse relationship in the functional expression of distal airway cell CFTR and $\mathrm{Ca}^{2+}$-activated $\mathrm{Cl}^{-}$conductance during intrauterine development, we speculate that a $\mathrm{Cl}^{-}$conductance other than CFTR may be an important determinant of fluid secretion from distal airway epithelial cells during early gestation in the rat. This inverse relationship occurring during the transition of secretion to absorption is in accord with a model of distal airway epithelial cell differentiation in which the suppression of gene functional expression is associated with the induction of expression of new cell-specific genes (36).

Acknowledgments. The authors thank P. Lembessis and F. Ghibu for their assistance.

\section{REFERENCES}

1. Strang LB 1991 Fetal lung liquid: secretion and reabsorption. Physiol Rev 71:991-1016

2. Cassin S, Perks AM 1982 Studies of factors which stimulate fluid secretion in fetal goats. J Dev Physiol 4:311-325

3. McCray PB, Welsh MJ 1991 Developing fetal alveolar epithelial cells secrete fluid in primary culture. Am J Physiol 260:L494-L500

4. O'Brodovich $\mathrm{H} 1991$ Epithelial ion transport in the fetal and perinatal lung. Am J Physiol 261:C555-C564

5. Donowitz M, Welsh MJ $1986 \mathrm{Ca}^{2+}$ and cyclic AMP in regulation of intestinal $\mathrm{Na}, \mathrm{K}$ and $\mathrm{Cl}$ transport. Annu Rev Physiol 48:135-150

6. Hartmann T, Verkman VS 1990 Model of ion transport regulation in chloridesecreting airway epithelial cells. Biophys J 58:391-401

7. Quinton PM 1990 Cystic fibrosis: a disease in electrolyte transport. FASEB J 4:2709-2717

8. Welsh MJ, Smith PL, Fromm M, Frizzell RA 1983 Crypts are the site of intestinal fluid and electrolyte secretion. Science 218:1219-1221

9. McCray PB, Reenstra W, Lonie E, Johnston J, Bettencourt J, Bastacky J 1992 Expression of CFTR and presence of CAMP-mediated fluid secretion in human fetal lung. Am J Physiol 262:L472-L481

10. Bear CE, Li C, Kartner N, Bridges RJ, Jensen TJ, Ramjeesingh M, Riordan JR 1992 Purification and functional reconstitution of the cystic fibrosis transmembrane conductance regulator (CFTR). Cell 68:809-818

11. Foskett JK, Melvin JE 1989 Activation of salivary secretion: coupling of cell volume and $\left[\mathrm{Ca}^{2+}\right]_{i}$ in single cells. Science $244: 1582-1585$

12. Suzuki Y, Ohtsuyama M, Samman G, Sato F, Sato K 1991 Ionic basis of methacholine-induced shrinkage of dissociated eccrine clear cells. J Membr Biol 123:33-41

13. Melvin JE, Kawaguchi M, Baum BJ, Turner RJ 1987 A muscarinic agoniststimulated chloride efflux pathway is associated with fluid secretion in rat parotid acinar cells. Biochem Biophys Res Commun 145:754-755

14. Nauntofle B, Dissing $S 1988 \mathrm{~K}^{+}$transport and membrane potential in isolated rat parotid acini. Am J Physiol 255:C508-C518

15. Iwatsuki N, Maruyama Y, Matsumoto O, Nishiyma A 1985 Activation of $\mathrm{Ca}^{2+}$ dependent $\mathrm{Cl}^{-}$and $\mathrm{K}^{+}$conductance in rat and mouse parotid acinar cells. Jpn J Physiol 35:933-944

16. Post M, Torday J, Smith BT 1984 Alveolar type II cells isolated from fetal rat lung organotypic cultures synthesize and secrete surfactant associated phospholipids and respond to fibroblast pneumocyte factor. Exp Lung Res 7:5365

17. O'Brodovich H, Hannam V, Rafii B 1991 Sodium channel but neither $\mathrm{Na}^{+}$. $\mathrm{H}^{+}$nor $\mathrm{Na}^{+}$-glucose symport inhibitors slow neonatal lung water clearance. Am J Respir Cell Mol Biol 5:377-384

18. O'Brodovich H, Rafii B, Post M 1990 Bioelectric properties of fetal alveolar epithelial monolayers. Am J Physiol 258:L201-L206

19. O'Brodovich H, Staub O, Rossier BC, Geering K, Kraehenbuhl JP 1993 Ontogeny of $\alpha_{1^{-}}$and $\beta_{1}$-isoforms of $\mathrm{Na}^{+}-\mathrm{K}^{+}$-ATPase in fetal distal lung epithelium. Am J Physiol 264:C1137-C1143

20. Rommens JM, Iannuzzi M, Kerem BS, Drumm ML, Melmer G, Dean M, Rozmahel R, Cole JL, Kennedy D, Hidaka N, Zsiga M, Buchwald M, Riordan JR, Tsui L-C, Collins FS 1989 Identification of the cystic fibrosis gene: chromosome walking and jumping. Science 245:1059-1065

21. MacLeod RJ, Hamilton JR 1990 Regulatory volume increase in mammalian jejunal villus cells is due to bumetanide-sensitive $\mathrm{NaKCl}_{2}$ cotransport. Am J Physiol 258:G665-G674

22. MacLeod RJ, Hamilton JR 1991 Separate $\mathrm{K}^{+}$and $\mathrm{Cl}^{-}$transport pathways are activated for regulatory volume decrease in jejunal villus cells. Am J Physiol 260:G405-G415

23. MacLeod RJ, Lembessis P, Hamilton JR 1992 Effect of protein kinase C inhibitors of $\mathrm{Cl}^{-}$conductance required for volume regulation after $\mathrm{L}$-alanine cotransport. Am J Physiol 262:C950-C955

24. MacLeod RJ, Lembessis P, Hamilton JR 1992 Effect of osmotic swelling on $\mathrm{K}^{+}$conductance in jejunal crypt epithelial cells. Am J Physiol 262:G1021G1026

25. Welsh MJ 1984 Anthracene-9-carboxylic acid inhibits an apical chloride conductance in canine tracheal epithelium. J Membr Biol 78:61-71

26. Sorscher EJ, Kirk KL, Weaver ML, Jilling T, Blalock JF, LeBoeuf RD 1991 Antisense oligodeoxynucleotides to the cystic fibrosis gene inhibits anion transport in normal cultured sweat duct cells. Proc Natl Acad Sci USA 88:7759-7762

27. Cliff WH, Frizzell RA 1990 Separate $\mathrm{Cl}^{-}$conductances activated by cAMP and $\mathrm{Ca}^{2+}$ in $\mathrm{Cl}^{-}$secreting epithelial cells. Proc Natl Acad Sci USA 87:49564960 
28. Heikkila R, Schwab G, Wickstrom E, Loke SL, Phiznik DH, Watt R, Neckers LM 1987 A C-myc antisense oligodNT inhibits entry into $S$ phase but not progress from $G_{0}$ to $G_{1}$. Nature 328:445-449

29. Krauss RD, Gabor B, Rado TA, Bubien JK 1992 Antisense oligonucleotides to CFTR confer a cystic fibrosis phenotype on B lymphocytes. Am J Physiol 263:C1147-C1151

30. Kopelman H, Gauthier C, Bornstein M 1993 Antisense oligodeoxynucleotide to CFTR inhibits cAMP activated but not calcium activated anion transport in a human pancreatic duct cell line. J Clin Invest 91:1253-1257

31. Woolf TM, Melton DA, Jennings CGB 1992 Specificity of antisense oligonucleotides in vivo. Proc Natl Acad Sci USA 89:7305-7309
32. McGrath SA, Basu A, Zeitlin PL 1993 Cystic fibrosis gene and protein expression during fetal lung development. Am J Respir Cell Mol Biol 8:201208

33. Trezise A, Buchwald M 1991 In vivo cell-specific expression of the cystic fibrosis transmembrane conductance regulator. Nature 353:434-437

34. Chow CW, Landau L, Taussig L 1982 Bronchial mucous glands in the newborn with cystic fibrosis. Eur J Pediatr 139:240-243

35. Esterly JR, Oppenheimer EH 1968 Cystic fibrosis of the pancreas: structura changes in peripheral airways. Thorax 23:670-675

36. Brody JS, Williams M 1992 Pulmonary alveolar epithelial cell differentiation. Annu Rev Physiol 54:351-371 